\title{
Radiation-Induced Lipid Peroxidation Triggers Ferroptosis and Synergizes with
}

\section{Ferroptosis Inducers}

Ling F. Ye ${ }^{1}$, Kunal R. Chaudhary ${ }^{2}$, Fereshteh Zandkarimi ${ }^{1}$, Andrew D. Harken ${ }^{3}$, Connor

J. Kinslow ${ }^{2}$, Pavan S. Upadhyayula ${ }^{4}$, Athanassios Dovas ${ }^{5}$, Dominique M. Higgins ${ }^{4}$, Hui $\mathrm{Tan}^{1}$, Yan Zhang ${ }^{1}$, Manuela Buonanno ${ }^{3}$, Tony J. C. Wang ${ }^{2,6}$, Tom K. Hei ${ }^{2,6}$, Jeffrey N.

Bruce $^{4}$, Peter D. Canoll ${ }^{5,6}$, Simon K. Cheng ${ }^{2,6,{ }^{*}}$, Brent R. Stockwell ${ }^{1,6,7,8,}{ }^{*}$

\footnotetext{
${ }^{1}$ Department of Biological Sciences, Columbia University, New York, NY 10027, USA ${ }^{2}$ Department of Radiation Oncology, Vagelos College of Physicians and Surgeons, Columbia University Irving Medical Center, New York, NY 10032, USA.

${ }^{3}$ Radiological Research Accelerator Facility, Center for Radiological Research, Columbia University, Irvington, NY 10533, USA.

${ }^{4}$ Department of Neurological Surgery, Vagelos College of Physicians and Surgeons, Columbia University Irving Medical Center, New York, NY 10032, USA

${ }^{5}$ Departments of Pathology and Cell Biology, Vagelos College of Physicians and Surgeons, Columbia University Irving Medical Center, 1130 St. Nicholas Ave Rm.1001, New York, NY, 10032, USA.

${ }^{6}$ Herbert Irving Comprehensive Cancer Center, Columbia University Irving Medical Center, New York, NY 10032, USA

${ }^{7}$ Department of Chemistry, Columbia University, New York, NY 10027, USA

${ }^{8}$ Lead contact

${ }^{*}$ Correspondence: bstockwell@columbia.edu (B.R.S.) and sc3225@cumc.columbia.edu (S.K.C.)
} 


\section{METHODS}

\section{RESOURCES}

\begin{tabular}{|c|c|c|}
\hline REAGENT & SOURCE & IDENTIFIER \\
\hline \multicolumn{3}{|l|}{$\overline{\text { Antibodies }}$} \\
\hline Anti-phospho histone-H2AX antibody & Millipore & $\underline{05-636}$ \\
\hline $\begin{array}{l}\text { Fluorescein (FITC) AffiniPure Goat Anti-Mouse lgG } \\
(\mathrm{H}+\mathrm{L})\end{array}$ & 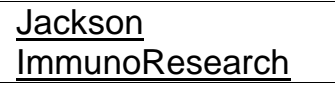 & $\underline{115-095-003}$ \\
\hline Anti-cleaved caspase 3 antibody & $\frac{\text { Cell Signaling }}{\text { Technology }}$ & $\underline{9661}$ \\
\hline Anti-beta actin antibody & Sigma-Aldrich & A5316 \\
\hline Peroxidase AffiniPure Goat Anti-Rabbit lgG $(\mathrm{H}+\mathrm{L})$ & $\begin{array}{l}\text { Jackson } \\
\text { ImmunoResearch }\end{array}$ & $\underline{111-035-144}$ \\
\hline Anti-4 Hydroxynonenal antibody & Abcam & ab46545 \\
\hline $\begin{array}{l}\text { Rhodamine Red }{ }^{\mathrm{TM}}-\mathrm{X}(\mathrm{RRX}) \text { AffiniPure Goat Anti-Rabbit } \\
\lg \mathrm{G}(\mathrm{H}+\mathrm{L})\end{array}$ & 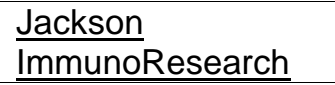 & $\underline{111-295-144}$ \\
\hline $\begin{array}{l}\text { Anti-dihydropyridine-MDA-lysine adduct mouse mAb } \\
\text { 1F83 }\end{array}$ & $\overline{\text { Reference }^{1}}$ & $\underline{N} / \mathrm{A}$ \\
\hline Goat Anti-Mouse IgG H\&L (FITC) & Abcam & $\underline{\mathrm{ab} 6785}$ \\
\hline \multicolumn{3}{|l|}{ Chemicals, Peptides, and Recombinant Proteins } \\
\hline Imidazole ketone erastin (IKE) & Reference $^{2}$ & $\mathrm{~N} / \mathrm{A}$ \\
\hline Ras-synthetic lethal 3 (RSL3) & $\overline{\text { Reference }^{3}}$ & $\underline{N} / \mathrm{A}$ \\
\hline Ferrostatin-1 (Fer-1) & Reference $^{4}$ & $\underline{\mathrm{N} / \mathrm{A}}$ \\
\hline Deferoxamine & Sigma-Aldrich & $\overline{\mathrm{D} 9533}$ \\
\hline Z-VAD-FMK & $\underline{\text { Selleck Chemicals }}$ & $\underline{\mathrm{S} 7023}$ \\
\hline$\overline{\text { Necrostatin-1S }}$ & $\overline{\text { Abcam }}$ & $\overline{\mathrm{ab221984}}$ \\
\hline 3-Methyladenine & Sigma-Aldrich & M9281 \\
\hline Trolox & Sigma-Aldrich & $\underline{238813}$ \\
\hline$\overline{\text { Staurosporine }}$ & Selleck Chemicals & $\overline{\underline{\mathrm{S} 1421}}$ \\
\hline Doxorubicin & ApexBio & A3966 \\
\hline Rapamycin & PeproTech & 5318893 \\
\hline Recombinant human TNFa & $\underline{\mathrm{ABM}}$ & Z100859 \\
\hline Birinapant & BioVision & $2597-1$ \\
\hline \multicolumn{3}{|l|}{ Critical Commercial Assays } \\
\hline GSH/GSSG Ratio Detection Assay Kit & Abcam & ab13881 \\
\hline TBARS Assay Kit & Cayman & $\underline{700870}$ \\
\hline BODIPY 581/591 C11 & $\begin{array}{l}\text { Thermo Fisher } \\
\text { Scientific }\end{array}$ & D3861 \\
\hline CellTiter-Glo Luminescent Cell Viability Assay & Promega & $\underline{G 7573}$ \\
\hline RNAeasy extraction kit & $\overline{\text { QIAGEN }}$ & $\overline{74106}$ \\
\hline QIAshredder & $\overline{\text { QIAGEN }}$ & 79656 \\
\hline High Capacity cDNA Reverse Transcription Kit & $\begin{array}{l}\text { Thermo Fisher } \\
\text { Scientific }\end{array}$ & $\underline{4368814}$ \\
\hline Power SYBR Green PCR Master Mix & $\begin{array}{l}\text { Thermo Fisher } \\
\text { Scientific }\end{array}$ & $\underline{4368702}$ \\
\hline \multicolumn{3}{|l|}{ Software and Algorithms } \\
\hline Prism, Version 7.0 & GraphPad Software & $\begin{array}{l}\text { https://www.graphpa } \\
\text { d.com/scientific- } \\
\text { software/prism/ }\end{array}$ \\
\hline
\end{tabular}




\begin{tabular}{|c|c|c|}
\hline MassLynx, Version 4.1 & $\underline{\text { Waters }}$ & $\begin{array}{l}\text { http://www.waters.co } \\
\text { m/waters/en US/Ma } \\
\text { ssLynx-Mass- } \\
\text { Spectrometry- } \\
\text { Software- }\end{array}$ \\
\hline XCMS package, Version 3.2.0 & Bioconductor & $\begin{array}{l}\text { http://packages.renij } \\
\text { n.org/package/org.re } \\
\text { njin.bioconductor/xc } \\
\text { ms }\end{array}$ \\
\hline
\end{tabular}

\section{CONTACT FOR REAGENT AND RESOURCE SHARING}

Further information and requests for resources and reagents should be directed to and will be fulfilled by the Lead Contact Brent R. Stockwell (bstockwell@columbia.edu).

\section{EXPERIMENTAL MODEL AND SUBJECT DETAILS}

Cell lines and cell culture information is listed below. The HT-1080 (male), SK-LMS-1 (female), U87 (male), and A549 (male) were obtained from ATCC. PC9 (male) cells were obtained from Sigma-Aldrich. HT-1080 cells were cultured in DMEM with 10\% fetal bovine serum, $1 \%$ penicillin-streptomycin and $1 \%$ non-essential amino acids. SK-LMS-1 cells were cultured in EMEM with 10\% fetal bovine serum and $1 \%$ penicillinstreptomycin. U87 cells were cultured in in DMEM with $10 \%$ fetal bovine serum and $1 \%$ penicillin-streptomycin. A549 cells were cultured in DMEM with 10\% fetal bovine serum and $1 \%$ penicillin-streptomycin. PC9 cells were cultured in RPMI with 10\% fetal bovine serum and $1 \%$ penicillin-streptomycin. All cells were maintained in a humidified environment at $37^{\circ} \mathrm{C}$ and $5 \% \mathrm{CO}_{2}$ in an incubator.

The animal models used in the paper is listed below. All animal study protocols were approved by the Columbia University Institutional Animal Care and Use Committee (IACUC). Athymic nude mice (Charles River Laboratories, strain code 490) (male, 8 
weeks of age) and NSG mice (The Jackson Laboratory, female, 8 weeks of age) were acclimated after shipping for $>3$ days before beginning experiments. Mice were fed a standard diet and maintained with no more than 5 mice per cage.

\section{Clonogenic assays}

500 cells were seeded per well in 6-well plates in their respective growth media and incubated overnight. The next day, cells were co-treated with DMSO or compounds and radiation using a Gammacell 40 Caesium-137 irradiator (Theratronics). Plates were monitored every day using a light microscope for formation of colonies in the DMSOtreated wells. When colonies of $>50$ cells are clearly visible, the growth medium was discarded from all plates. The cells were washed with PBS, then fixed and stained with crystal violet solution ( $0.05 \%$ crystal violet, $1 \%$ formaldehyde, $1 \%$ methanol in PBS). Colonies were then directly visualized and counted.

\section{Cell Titer Glo assay}

HT-1080 cells were plated at 1,000 cells per well in white 96 -well plates (100 uL per well) in technical duplicates. The cells were then treated with vehicle (DMSO), Ferrostatin-1, DFO, Z-VAD-FMK or Necrostatin-1S and incubated overnight. After $24 \mathrm{~h}$ incubation, cells were treated with 0 Gy or 2 Gy radiation using a Gammacell 40 Caesium-137 irradiator (Theratronics) and incubated overnight. After another 24 h, 100 uL of $50 \%$ Cell Titer Glo (Promega) $50 \%$ cell culture medium was added to each well and incubated at room temperature with shaking for $15 \mathrm{~min}$. Luminescence was 
measured using a Victor X5 plate reader (PerkinEImer). Experiments were performed three independent times with different passages for each cell line.

\section{RT-qPCR}

RNA was extracted using the Qiashredder and QIAGEN RNeasy Mini kits (QIAGEN) according to the manufacturer's protocol. $2 \mu \mathrm{g}$ total RNA for each sample was used as input for each reverse transcription reaction. Quantitative PCR reactions were performed using the Power SYBR Green PCR Master Mix (Thermo Fisher Scientific). Triplicate samples per condition were analyzed on an Applied Biosystems 7300 qPCR instrument using absolute quantification settings. Differences in mRNA levels compared to $A C T B$ internal reference control were computed between control and experimental conditions using the $\Delta \triangle \mathrm{Ct}$ method. The primers used in this study are listed below. ACTB forward: 5'-AGAGCTACGAGCTGCCTGAC-3'

ACTB reverse: 5'-AGCACTGTGTTGGCGTACAG-3'

PTGS2 forward: 5'-ATATGTTCTCCTGCCTACTGGAA-3'

PTGS2 reverse: 5'-GCCCTTCACGTTATTGCAGATG-3'

\section{TBARS assay}

2 million cells were seeded in T175 flasks. The next day, cells were treated with compounds and/or radiation to induce MDA formation and incubated overnight. $24 \mathrm{~h}$ later, the cells were harvested, counted, and collected at $300 \times g$ at $4{ }^{\circ} \mathrm{C}$ for $5 \mathrm{~min}$. The cell pellet was resuspended in $100 \mu$ l of RIPA buffer and homogenized by pipetting. The 
whole lysate was used to determine MDA concentration in each sample. We used the TBARS assay kit (Cayman Chemical) and followed the product instructions.

\section{Lipid ROS assay using flow cytometry}

0.5 million cells were seeded in $10 \mathrm{~cm}$ dishes. The next day, they were co-treated with ferroptosis-modulating compounds and radiation and returned to the incubator. On the following day, cells were harvested in $15 \mathrm{ml}$ tubes and washed twice with PBS followed by re-suspending in $500 \mu$ of PBS containing $10 \mu \mathrm{M}$ of BODIPY-C11 dye (Thermo Fisher Scientific, cat\# D3861), and incubated at $37^{\circ} \mathrm{C}$ for 30 minutes. The cells were then collected at $300 \times g$ for 5 minutes, washed with PBS three times, and subjected to the flow cytometry analysis. C6 flow cytometry system (BD Accuri cytometers) was used for the flow cytometer analysis. A minimum of 10,000 cells were analyzed per condition.

\section{Glutathione measurement}

1 million cells were seeded on $10 \mathrm{~cm}$ dishes. The next day, cells were treated with compounds and/or radiation to induce GSH depletion and incubated overnight. $24 \mathrm{~h}$ later, the cells were harvested and counted. Five million live cells from each sample were transferred to new tubes, and centrifuged at $300 \times g$ at $4{ }^{\circ} \mathrm{C}$ for $5 \mathrm{~min}$. The cell pellet was resuspended in $100 \mu$ l of RIPA buffer and homogenized by pipetting. The lysate was centrifuged at $16,700 \times g$ at $4{ }^{\circ} \mathrm{C}$ for $15 \mathrm{~min}$, and cleared lysate was used to determine the amount of GSH in the sample. We used the GSH/GSSG ratio detection assay kit (Abcam, \#ab138881) and followed the product instructions to determine GSH levels. 


\section{Immunofluorescence study and quantification of cells}

10,000 cells were seeded on cover slips placed inside wells of 6 -well plates. The next day, cells were treated with ferroptosis modulators and/or radiation, then returned to the incubator for 30 minutes or 6 hours. After the growth medium was removed, the cells were washed with PBS and fixed with $100 \mu \mathrm{l}$ 4\% paraformaldehyde per well for 10 minutes at room temperature. After three washes with PBS, cells were permeabilized with $100 \mu$ I Triton X-100 (0.1\% v/v) per well for 10 minutes incubation at room temperature. Non-specific protein binding was blocked with $100 \mu \mathrm{l}$ of BSA (1\% v/v) per well for 20 minutes at room temperature. After removing excess BSA, 100 $\mu$ l of primary mouse monoclonal anti-phospho histone-H2AX antibody (1:500) was added to each well for a 1-hour incubation at room temperature. Cells were washed with PBS and incubated with $100 \mu \mathrm{l}$ of secondary antibody per well for 45 minutes at room temperature in the dark. Cells were washed with PBS and mounted on slides with one drop of Prolong anti-fade reagent with DAPI (Invitrogen) per coverslip. Slides were stored at $4{ }^{\circ} \mathrm{C}$ in the dark before analysis on a Zeiss LSM 700 confocal microscope with constant laser intensity for all analyzed samples.

\section{Comet assay}

100,000 HT-1080 cells were seeded per well in 6-well plates and incubated overnight. On the next day, the cells were treated with ferroptosis modulators and/or radiation, then returned to the incubator for 30 minutes or 4 hours before being harvested with trypsin and counted. The comet assay was performed using the CometAssay kit 
(Trevigen) following the alkaline comet assay product instructions. All images were captured on a Zeiss LSM 700 confocal microscope with constant laser intensity for all analyzed samples. The fluorescent signal of each comet was analyzed using NIH ImageJ software.

\section{Western blot}

1 million cells were seeded in $10 \mathrm{~cm}$ dishes and treated with compounds and/or radiation on the next day. After 24 hours, cells were harvested at $300 \times g$ at $4{ }^{\circ} \mathrm{C}$ for 5 min, resuspended in $50 \mu \mathrm{l}$ of RIPA buffer and homogenized by pipetting. After quantification by Bradford, samples were mixed with 5X SDS loading buffer and separated by SDS-polyacrylamide gel electrophoresis. After transfer, membranes were blocked for 10 min in Tris-buffered saline (pH 7.4) with 1\% Tween-20 (TBS-T) with 5\% milk and incubated in primary antibody overnight at $4{ }^{\circ} \mathrm{C}$. Following $3 \mathrm{X}$ for 5 min washes in TBS-T, the membrane was incubated with secondary antibodies for $1 \mathrm{hr}$. The membrane was washed again in TBST $3 X$ for 5 min prior to visualization using enhanced chemiluminescence (ECL Western Blotting Substrate, Pierce). Antibody for cleaved caspase 3 (Cell Signaling Technology, \#9661) was used at 1:1000 and detected using a Peroxidase AffiniPure Goat Anti-Rabbit lgG $(\mathrm{H}+\mathrm{L})$ (Jackson ImmunoResearch, 111-295-144) at 1:5000 dilution.

\section{Mass spectrometry-based untargeted lipidomics}

\section{Sample preparation}


Lipids were extracted from each sample as described previously 5.5 million cells treated with DMSO or $5 \mu \mathrm{M}$ IKE for 12 hours, with or without 6 Gy radiation for 24 hours, were scraped and homogenized in $250 \mathrm{~mL}$ cold methanol containing $0.01 \%$ butylated hydroxyl toluene $(\mathrm{BHT})$ with micro tip sonicator. Homogenized samples were transferred to fresh glass tubes containing $850 \mathrm{~mL}$ of cold methyl-tertbutyl ether (MTBE) and vortex-mixed for $30 \mathrm{sec}$. To enhance extraction efficiency of lipids, the samples were incubated for one hour at $4^{\circ} \mathrm{C}$ on an orbital shaker. Afterwards, $200 \mathrm{~mL}$ of cold water was added to each sample, and incubated for 20 min on ice before centrifugation at $3,000 \mathrm{rpm}$ for $20 \mathrm{~min}$ at $4^{\circ} \mathrm{C}$. The organic layer was collected followed by drying under a gentle stream of nitrogen gas on ice and stored at $-80^{\circ} \mathrm{C}$ until UPLC-MS analysis. The protein pellet was used to measure protein concentration for normalization using BioRad protein assay. The samples were re-constituted in a solution containing 2-propanol/ acetonitrile/water $(4: 3: 1, \mathrm{v} / \mathrm{v} / \mathrm{v})$ containing mixture of internal standard (PLASH® LIPIDOMIX® Mass Spec Standard, Avanti Polar Lipids, INC.) for further UPLC-MS analysis. A quality control (QC) sample was prepared by combining $40 \mathrm{~mL}$ of each sample to assess the reproducibility of the features through the runs.

\section{Ultra-high-performance liquid chromatography analysis}

Chromatographic separation of extracted lipids was carried out at $55^{\circ} \mathrm{C}$ on ACQUITY

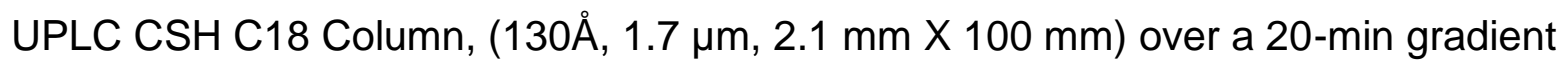
elution. Mobile phase A consisted of ACN/water (60:40, v/v) and mobile phase B was 2propanol/ACN/water $(85: 10: 5, \mathrm{v} / \mathrm{v} / \mathrm{v})$ both containing $10 \mathrm{mM}$ ammonium acetate and $0.1 \%$ acetic acid. After injection, the gradient was held at $40 \%$ mobile phase B for 2 min. 
At $2.1 \mathrm{~min}$, it reached to $50 \% \mathrm{~B}$, then increased to $70 \% \mathrm{~B}$ in $12 \mathrm{~min}$. At $12.1 \mathrm{~min}$, changed to $70 \% \mathrm{~B}$ and in $18 \mathrm{~min}$ increased to $90 \% \mathrm{~B}$. The eluent composition returned to the initial condition in $1 \mathrm{~min}$, and the column was re-equilibrated for an additional 1 min before the next injection was conducted. The flow rate was set to $400 \mathrm{~mL} / \mathrm{min}$ and Injection volumes were $6 \mu \mathrm{L}$ using the flow through needle mode in both positive and negative ionization modes. The QC sample was injected between the samples and at the end of the run to monitor the performance and the stability of the MS platform. This QC sample was also injected at least 5 times at the beginning of the UPLC/MS run, in order to condition the column.

\section{Mass spectrometry analysis}

The Synapt G2 mass spectrometer (Waters, Manchester, U.K.) was operated in both positive and negative electrospray ionization (ESI) modes. For positive mode, a capillary voltage and sampling cone voltage of $3 \mathrm{kV}$ and $32 \mathrm{~V}$ were used. The source and desolvation temperature were kept at $120^{\circ} \mathrm{C}$ and $500^{\circ} \mathrm{C}$, respectively. Nitrogen was used as desolvation gas with a flow rate of $900 \mathrm{~L} / \mathrm{hr}$. For negative mode, a capillary voltage of $-2 \mathrm{kV}$ and a cone voltage of $30 \mathrm{~V}$ were used. The source temperature was $120^{\circ} \mathrm{C}$, and desolvation gas flow was set to $900 \mathrm{~L} / \mathrm{hr}$. Dependent on the ionization mode the protonated molecular ion of leucine encephalin $\left([\mathrm{M}+\mathrm{H}]^{+}, \mathrm{m} / \mathrm{z} 556.2771\right)$ or the deprotonated molecular ion ([M-H] $\left.]^{-}, \mathrm{m} / \mathrm{z} 554.2615\right)$ was used as a lock mass for mass accuracy and reproducibility. Leucine enkephalin was introduced to the lock mass at a concentration of $2 \mathrm{ng} / \mathrm{mL}$ ( $50 \%$ ACN containing $0.1 \%$ formic acid), and a flow rate of 10 $\mathrm{mL} / \mathrm{min}$. The data was collected in duplicates in the centroid data independent (MS ${ }^{\mathrm{E}}$ ) 
mode over the mass range $\mathrm{m} / \mathrm{z} 50$ to $1600 \mathrm{Da}$ with an acquisition time of 0.1 seconds per scan. The QC samples were also acquired in enhanced data independent ion mobility (IMS-MSE) in both positive and negative modes for enhancing the structural assignment of lipid species. The ESI source settings were the same as described above. The traveling wave velocity was set to $650 \mathrm{~m} / \mathrm{s}$ and wave height was $40 \mathrm{~V}$. The helium gas flow in the helium cell region of the ion-mobility spectrometry (IMS) cell was set to $180 \mathrm{~mL} / \mathrm{min}$ to reduce the internal energy of the ions and minimize fragmentation. Nitrogen as the drift gas was held at a flow rate of $90 \mathrm{~mL} / \mathrm{min}$ in the IMS cell. The low collision energy was set to $4 \mathrm{eV}$, and high collision energy was ramping from 25 to 65 $\mathrm{eV}$ in the transfer region of the T-Wave device to induce fragmentation of mobilityseparated precursor ions.

\section{Data pre-processing and statistical analysis}

All raw data files were converted to netCDF format using DataBridge tool implemented in MassLynx software (Waters, version 4.1). Then, they were subjected to peak-picking, retention time alignment, and grouping using XCMS package (version 3.2.0) in $\mathrm{R}$ (version 3.5.1) environment. For the peak picking, the CentWave algorithm was used with the peak width window of $2-25 \mathrm{~s}$. For peak grouping, bandwidth and $\mathrm{m} / \mathrm{z}$-width of 2 s and 0.01 Da were used, respectively. After retention time alignment and filling missing peaks, an output data frame was generated containing the list of time-aligned detected features ( $\mathrm{m} / \mathrm{z}$ and retention time) and the relative signal intensity (area of the chromatographic peak) in each sample. Technical variations such as noise were assessed and removed from extracted features' list based on the ratios of average 
relative signal intensities of the blanks to $Q C$ samples (blank/QC $>1.5$ ). Also, peaks with variations larger than 30\% in QCs were eliminated. All the extracted features were normalized to measured protein concentrations measured by BCA assay. Statistical analysis was performed in R (version 3.5.1) environment. Group differences were calculated using two-way ANOVA $(p<0.05)$ and false discovery rate of $1 \%$ to control for multiple comparisons.

\section{Structural assignment of identified lipids}

Structural elucidation and validation of significant lipid features were initially obtained by searching monoisotopic masses against the available online databases such as METLIN, Lipid MAPS, and HMDB with a mass tolerance of 5 ppm. Fragment ion information obtained by tandem MS (UPLC-HDMSE) was utilized for further structural elucidation of significantly changed lipid species. HDMSE data were processed using MSE $^{E}$ data viewer (Version 1.3, Waters Corp., MA, USA).

\section{Microbeam irradiation and clonogenic assay}

The charged particle single cell microbeam at Radiological Research Accelerator Facility (RARAF) at the Center for Radiological Research, Columbia University was used. 300-500 HT-1080 cells were plated on polypropylene film treated with $3.5 \mu \mathrm{g} / \mathrm{cm}^{2}$ Cell-Tak adhesive (BD Biosciences). The next day, cells were stained with Hoechst 33342 for $30 \mathrm{~min}$. Cells were imaged, and their center-of-gravity coordinates were registered to automatically locate them by the microbeam control program. For nuclear irradiation, protons $\left({ }^{1} \mathrm{H}^{+}\right)$were directed by a precision beam to the center of the nucleus. 
For cytoplasmic irradiation, protons were directed to two locations $7 \mu \mathrm{m}$ away from the ends of the major axis of each nucleus, as previously described ${ }^{6}$. In each case, the beam has an accuracy of $\pm 0.2 \mu \mathrm{m}$ with $95 \%$ efficiency. Post-irradiation, cells were trypsinized and re-plated at a density of 500 cells per well in 6-well plates for clonogenic assays.

\section{Immunofluorescence study and quantification of microbeam-irradiated cells}

Microbeam-treated cells were washed three times with PBS, fixed for $15 \mathrm{~min}$ at room temperature in 4\% (w/v) paraformaldehyde in PBS and then washed in PBS. The fixed cells were permeabilized with $0.1 \%$ Triton $\mathrm{X}-100$ for $10 \mathrm{~min}$ and washed three times with PBS. The cells were incubated for $1 \mathrm{~h}$ at room temperature in PBS containing $5 \%(\mathrm{v} / \mathrm{v})$ goat serum and then incubated for $1 \mathrm{~h}$ in the same medium containing Anti-phospho histone-H2AX antibody (Millipore, 05-636, 1:500 dilution) or Anti-4 Hydroxynonenal antibody (Abcam, ab46545, 1:500 dilution). The cells were washed and bound primary antibodies were detected by the reaction with Fluorescein (FITC) AffiniPure Goat AntiMouse IgG $(\mathrm{H}+\mathrm{L})$ (Jackson ImmunoResearch, 115-095-003, 1:1000 dilution) or Rhodamine Red ${ }^{\mathrm{TM}}-\mathrm{X}(\mathrm{RRX})$ AffiniPure Goat Anti-Rabbit lgG $(\mathrm{H}+\mathrm{L})$ Jackson ImmunoResearch, 111-295-144, 1:1000 dilution) for $1 \mathrm{~h}$. Cells were thoroughly washed and the polypropylene layer was cut out and placed on a glass slide. A cover glass was placed on top of the polypropylene layer and mounted using ProLong Diamond antifade mountant with DAPI (ThermoFisher P36962). Samples were examined using a Zeiss LSM 700 confocal microscope with constant laser intensity for all analyzed samples. The intensity above threshold of the fluorescent signal of the bound antibodies was 
analyzed using NIH ImageJ software. Fluorescence intensity was obtained using the images generated by Image $\mathrm{J}$ software (NIH, Bethesda, MD, USA).

\section{HT-1080 tumor xenograft study in mice}

Athymic nude mice (8 weeks; Charles River Laboratories) were injected with four million HT-1080 cells s.c. After $\sim 14$ days, when the flank tumors had reached an average volume of approximately 100 cubic millimeters, mice were randomized into 4 groups (vehicle or IKE treatment +/- radiation). $300 \mu \mathrm{L}$ of vehicle (65\% D5W, 30\% PEG400, 5\% Tween-80) or $40 \mathrm{mg} / \mathrm{kg}$ IKE was delivered i.p. after sterilizing the solutions using a 0.2-micron syringe filter. The injections were repeated daily for 14 days. On days 2 and 4 of vehicle or IKE injections, 0 or 6 Gy radiation was delivered to the tumors using the Small Animal Radiation Research Platform (SARRP). For the sorafenib experiment, the formulation used was $40 \mathrm{mg} / \mathrm{kg}$ sorafenib in 5\% DMSO, 20\% ethanol in water containing $30 \% \mathrm{w} / \mathrm{v}$ cyclodextrin. Other experimental details were identical to the IKE experiment, with the exception that radiation was delivered on days 1 and 3 . Tumor size was measured daily using calipers and mouse weight was measured daily. The animal protocols containing all the procedures were approved by Columbia University's IACUC.

\section{Patient-derived xenograft study in mice}

Patient-derived xenograft tumor-bearing NSG cohort mice (TM00219, LG1049F Lung, 6-8 weeks of age) were purchased from The Jackson Laboratory. when the flank tumors had reached an average volume of approximately 60 cubic millimeters, mice were 
randomized into 4 groups (vehicle or IKE treatment or sorafenib treatment + /- radiation). The experiment was conducted according to the same protocol as the HT-1080 tumor xenograft study, with the exception that a single dose of radiation (sham or 6 Gy) was delivered to the tumor on day 1 of the experiment. The animal protocols containing all the procedures were approved by Columbia University's IACUC.

\section{Immunohistochemistry study and quantification on paraffin-embedded tissue} sections

Tumor tissue was fixed in $4 \%$ paraformaldehyde (PFA) for $24 \mathrm{~h}$ at $4{ }^{\circ} \mathrm{C}$ followed by washing three times with PBS. The samples were fixed in paraffin. Six series of $5 \mathrm{~mm}$ sections were obtained with a sliding microtome. The serial sections were then mounted on gelatin-coated slide. The paraffin-embedded tissue sections were deparaffinized with xylene three times, 5 min each, followed by rehydrating in $100 \%, 90 \%, 70 \%$, and $50 \%$ ethanol, two washes 5 min each, then rinsed with distilled water. Antigen retrieval was performed in sodium citrate buffer, $\mathrm{pH} 6.0,95-100^{\circ} \mathrm{C}$ for $10 \mathrm{~min}$. Sections were then rinsed in PBST, 2 min each. A hydrophobic barrier pen was used to draw a circle on each slide. The slides were permeabilized with PBS/0.4\% Triton X-100 twice before non-specific-binding blocking by incubating the sections with $10 \%$ goat serum (ThermoFisher 50197Z) for 30 minutes at room temperature. The sections were incubated with mouse anti-MDA mAb 1F83 (1:500 dilution) overnight at $4{ }^{\circ} \mathrm{C}$ in humidified chambers. Sections were washed with PBST for twice before incubating with goat anti-mouse IgG H\&L (FITC) (Abcam, ab6785, 1:1000 dilution) at room temperature for $1 \mathrm{~h}$. Slides were then washed twice with PBST. ProLong Diamond antifade mountant 
with DAPI (ThermoFisher P36962) was added onto slides, which were then covered with the coverslips, sealed by clear fingernail polish and observed under confocal microscopy. All images were captured on a Zeiss LSM 700 confocal microscope with constant laser intensity for all analyzed samples. The intensity above threshold of the fluorescent signal of the bound antibodies was analyzed using NIH ImageJ software.

\section{Quantification and statistical analysis}

T-test, one-way ANOVA, and two-way ANOVA were performed in the R environment and GraphPad Prism7 with significance and confidence level 0.05 (95\% confidence interval). 


\section{METHOD REFERENCES}

[1] Yamada, S., Kumazawa, S., Ishii, T., Nakayama, T., Itakura, K., Shibata, N., Kobayashi, M., Sakai, K., Osawa, T., and Uchida, K. (2001) Immunochemical detection of a lipofuscin-like fluorophore derived from malondialdehyde and lysine, J Lipid Res 42, 1187-1196.

[2] Larraufie, M. H., Yang, W. S., Jiang, E., Thomas, A. G., Slusher, B. S., and Stockwell, B. R. (2015) Incorporation of metabolically stable ketones into a small molecule probe to increase potency and water solubility, Bioorg Med Chem Lett 25, 4787-4792.

[3] Yang, W. S., SriRamaratnam, R., Welsch, M. E., Shimada, K., Skouta, R., Viswanathan, V. S., Cheah, J. H., Clemons, P. A., Shamii, A. F., Clish, C. B., Brown, L. M., Girotti, A. W., Cornish, V. W., Schreiber, S. L., and Stockwell, B. R. (2014) Regulation of ferroptotic cancer cell death by GPX4, Cell 156, 317-331.

[4] Skouta, R., Dixon, S. J., Wang, J., Dunn, D. E., Orman, M., Shimada, K., Rosenberg, P. A., Lo, D. C., Weinberg, J. M., Linkermann, A., and Stockwell, B. R. (2014) Ferrostatins inhibit oxidative lipid damage and cell death in diverse disease models, J Am Chem Soc 136, 4551-4556.

[5] Zhang, Y., Tan, H., Daniels, J. D., Zandkarimi, F., Liu, H., Brown, L. M., Uchida, K., O'Connor, O. A., and Stockwell, B. R. (2019) Imidazole Ketone Erastin Induces Ferroptosis and Slows Tumor Growth in a Mouse Lymphoma Model, Cell Chem Biol.

[6] Wu, L. J., Randers-Pehrson, G., Xu, A., Waldren, C. A., Geard, C. R., Yu, Z., and Hei, T. K. (1999) Targeted cytoplasmic irradiation with alpha particles induces mutations in mammalian cells, Proc Natl Acad Sci U S A 96, 4959-4964. 


\section{Figure S1. Related for Figure 1.}

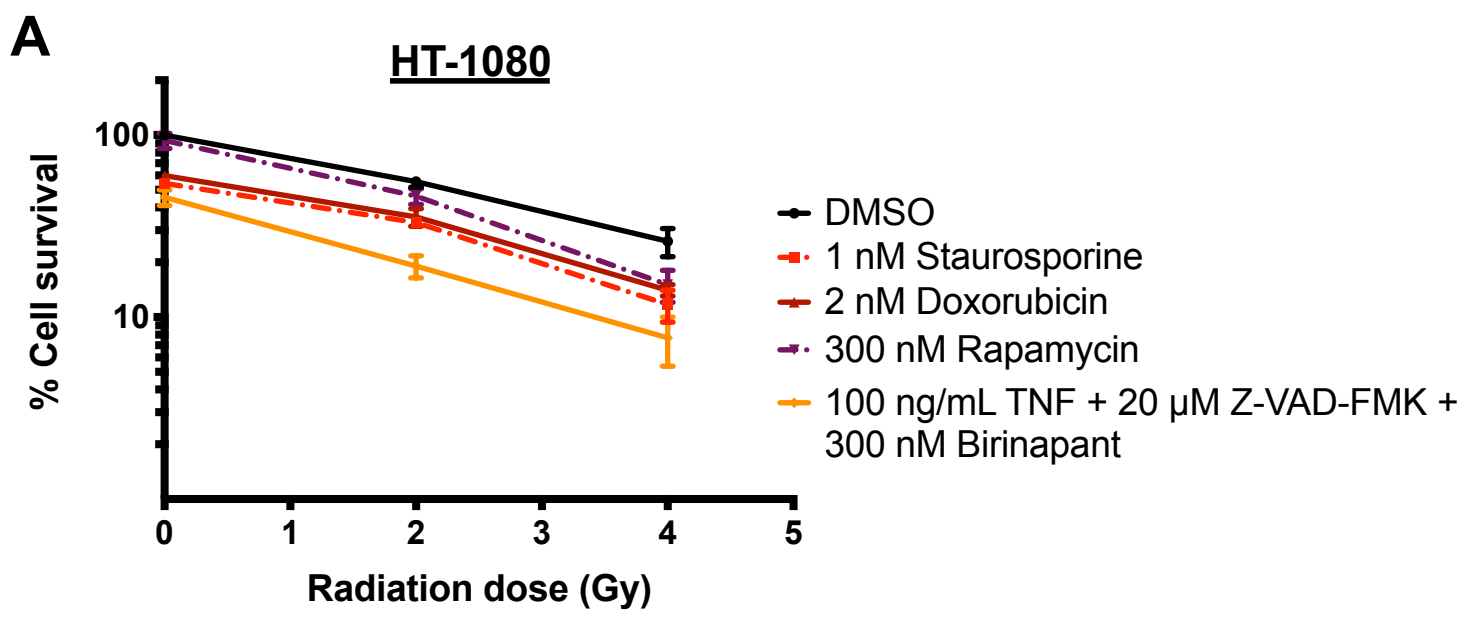

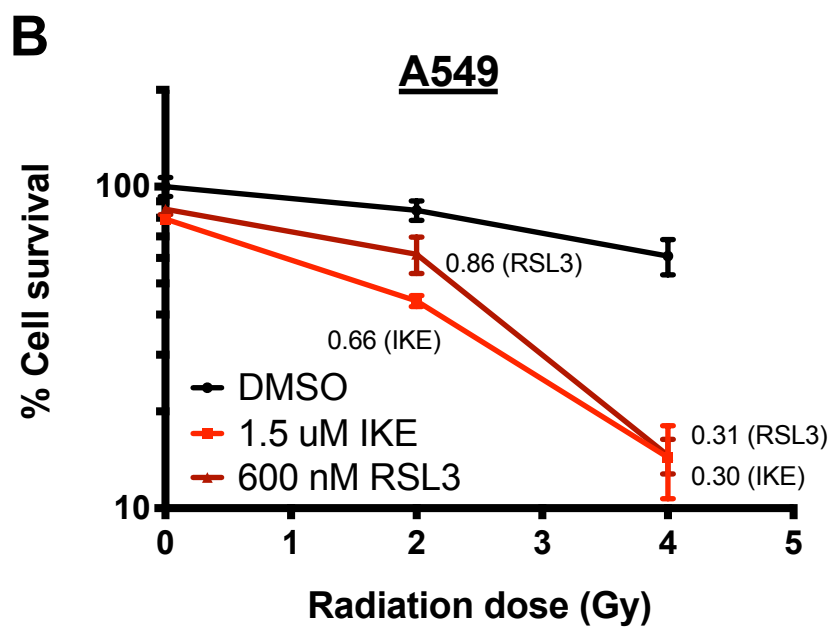

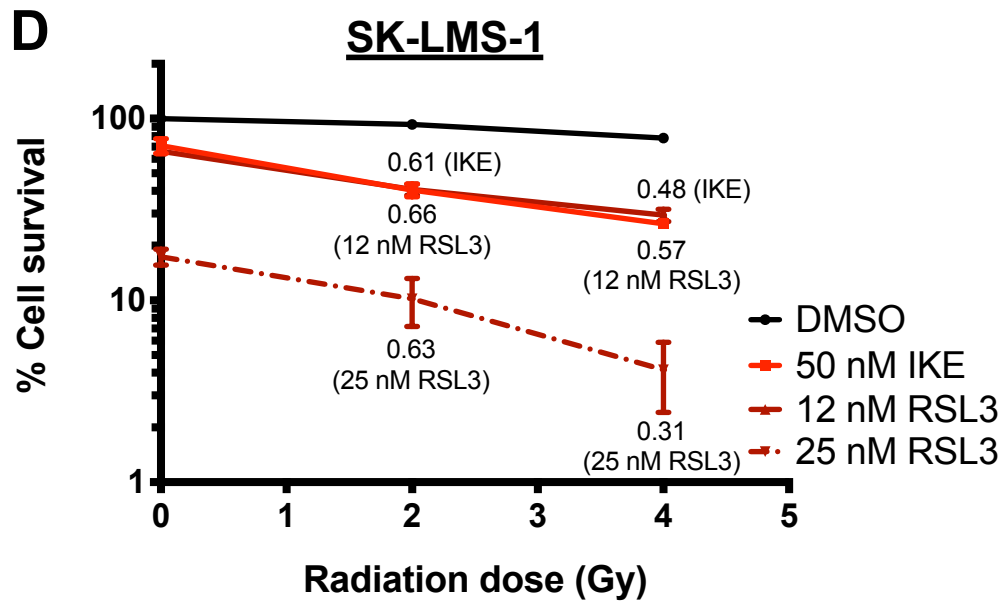

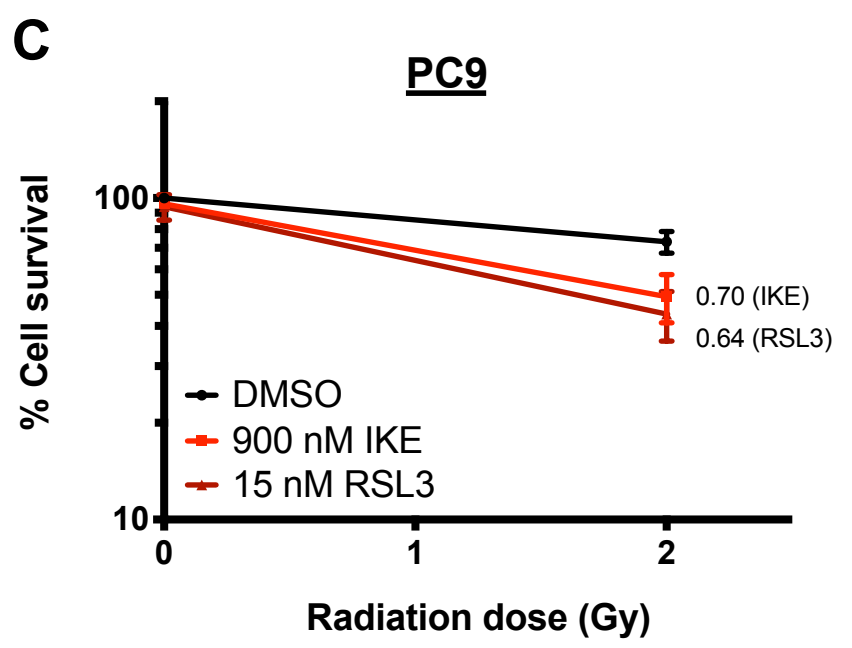

E

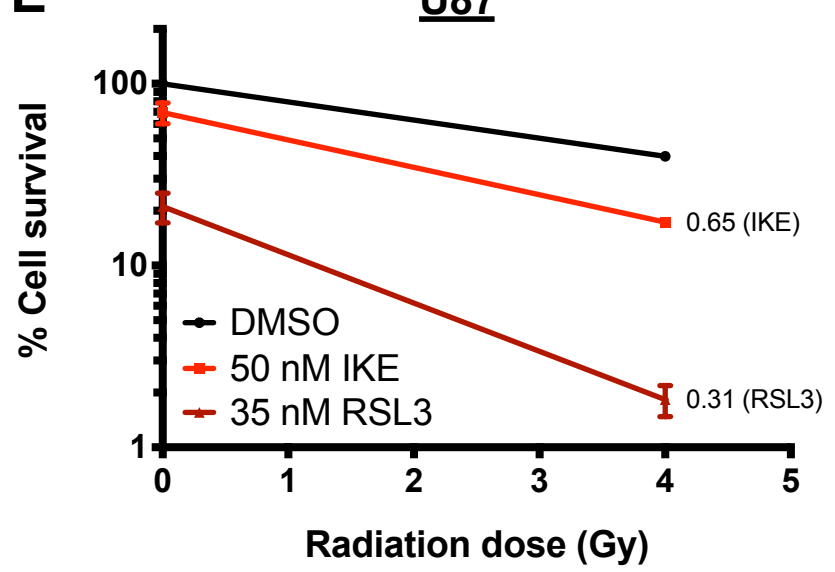

Figure S1. Related to Figure 1 and results section. Survival data of cell lines treated with cell death inducers. A) Dose response of HT-1080 cells treated with DMSO, staurosporine, doxorubicin, rapamycin, or TNFa + Z-VAD-FMK + Birinapant to radiation measured by clonogenic assays. B) to E) Dose response of A549, PC9, SK-LMS-1, and U87 cells treated with DMSO, IKE, or RSL3 to radiation measured by clonogenic assays. $C D I$ values are indicated next to data points according to the formula $C D I=A B /(A x$ $B)$, where $A B$ is the surviving fraction of the combination treatment, and $A$ and $B$ are the surviving fractions of the individual treatments. Data are plotted as mean $\pm S E M ; n=3$ for $A$ ) and $n=2$ for $B$ ) sideby-side replicates. Three biologically independent experiments were performed with similar results. 


\section{Figure S2. Related to Figure 2.}

\section{HT-1080}

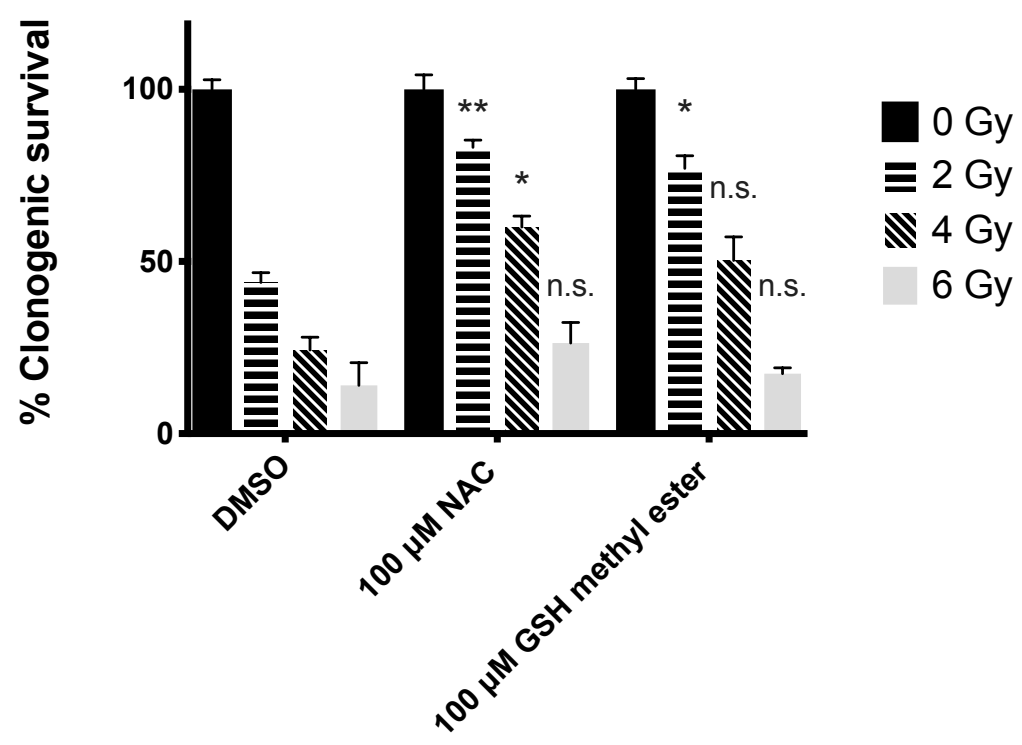

Figure S2. Related to Figure 2 and results section. Clonogenic survival of HT-1080 cells treated with vehicle, $\mathrm{N}$-acetylcysteine, or glutathione methyl ester to 0, 2, 4 and 6 Gy radiation. Data are plotted as mean \pm SEM; $n=2$ side-by-side replicates. The experiment was repeated twice with similar results. 


\section{Figure S3. Related to Figure 3.}

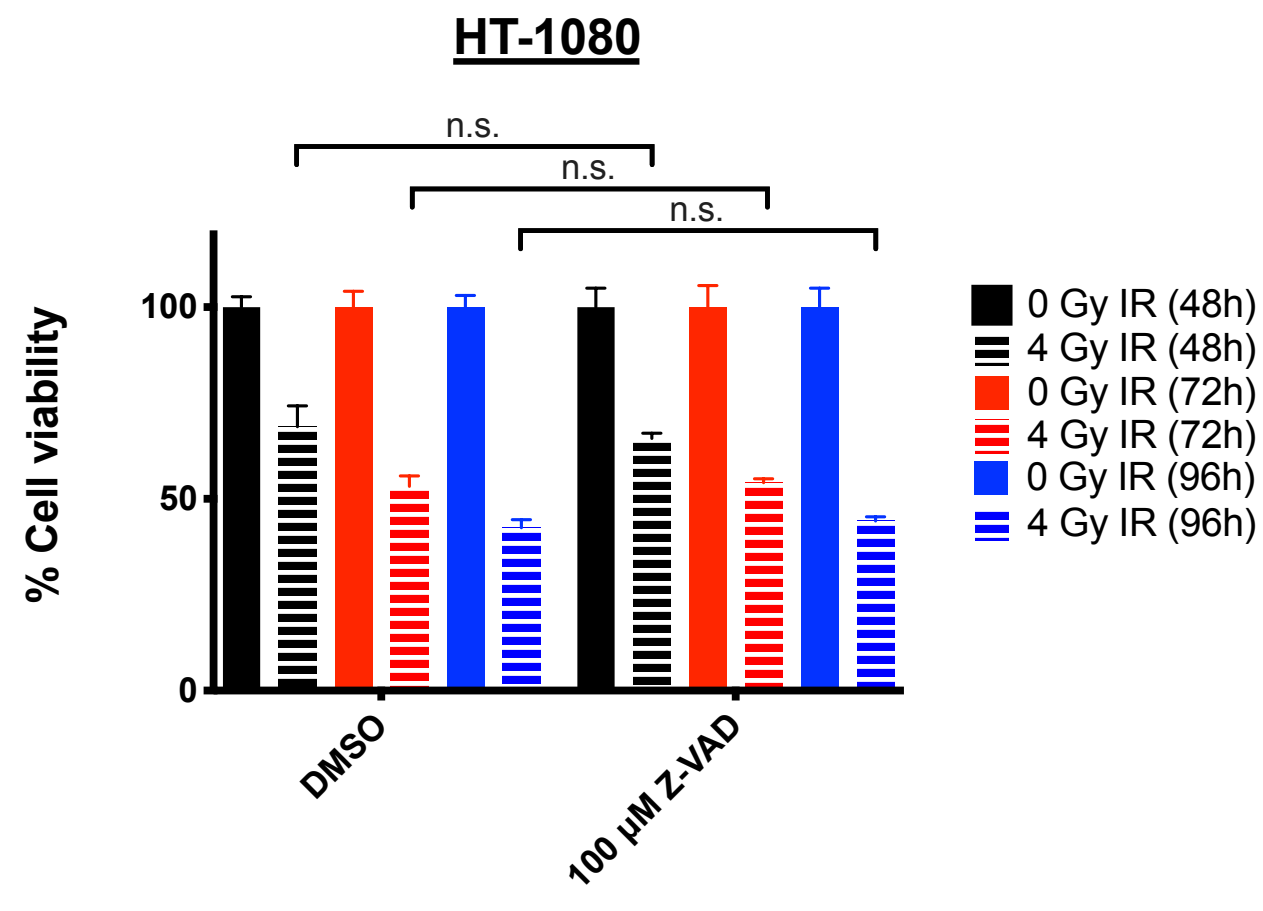

Figure S3. Related to Figure 3 and results section. Cell viability of HT-1080 cells treated with DMSO or Z-VAD-FMK and co-treated with 0 or 4 Gy radiation for 48, 72 or 96 hours measured by Cell Titer Glo. Data normalized to 0 Gy unirradiated controls for each group. Data are plotted as mean \pm SEM; $n=3$ side-by-side replicates. The experiment was repeated twice with similar results. 


\section{Figure S4. Related to Figure 5.}

$\underline{\mathrm{HT}-1080}$

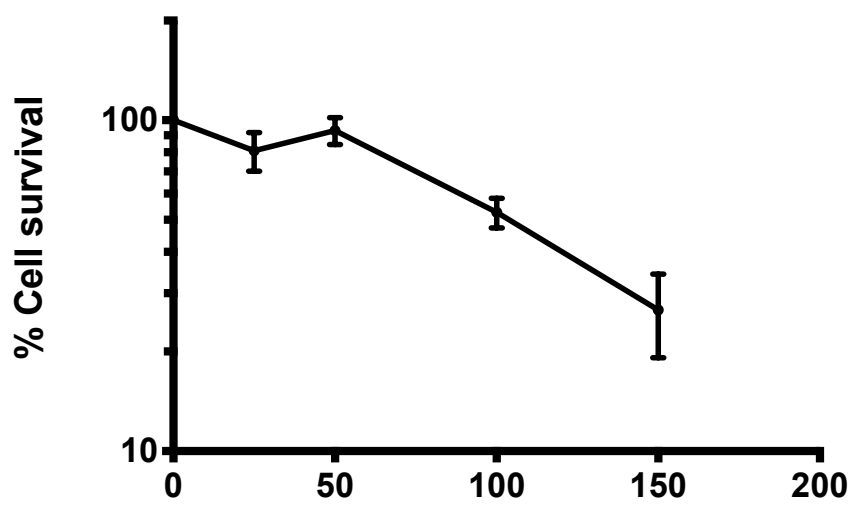

Radiation dose (number of protons to cell nucleus)

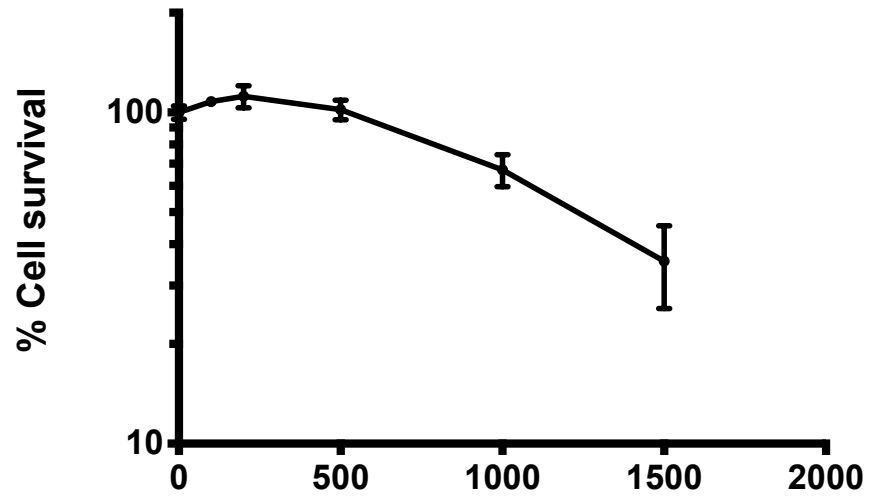

Radiation dose (number of protons per spot to cell cytoplasm)

Figure S4. Related to Figure 5 and results section. Dose response of HT-1080 cells treated with nuclear (left) or cytoplasmic (right) microbeam radiation, measured by clonogenic assays. Data are plotted as mean \pm SEM; $n=3$ side-by-side replicates. 
Figure S5. Related to Figure 6.

A HT-1080 xenograft

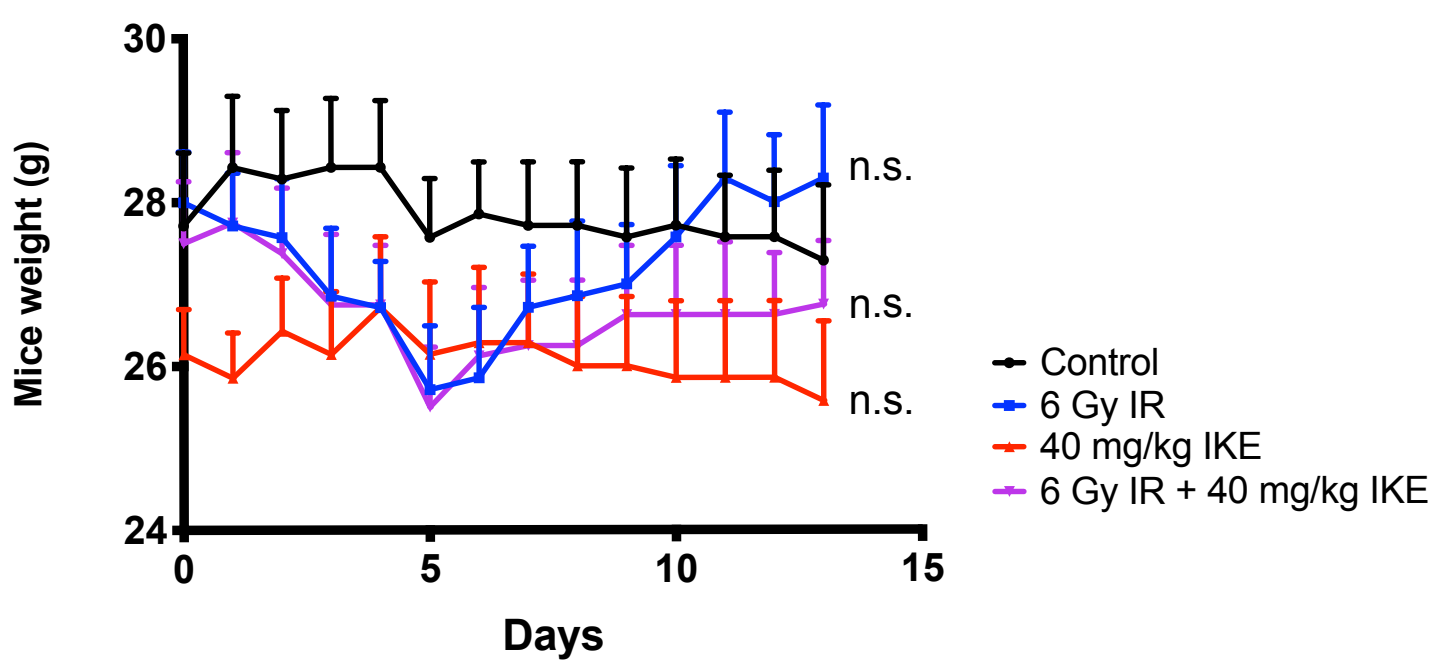

B

HT-1080 xenograft

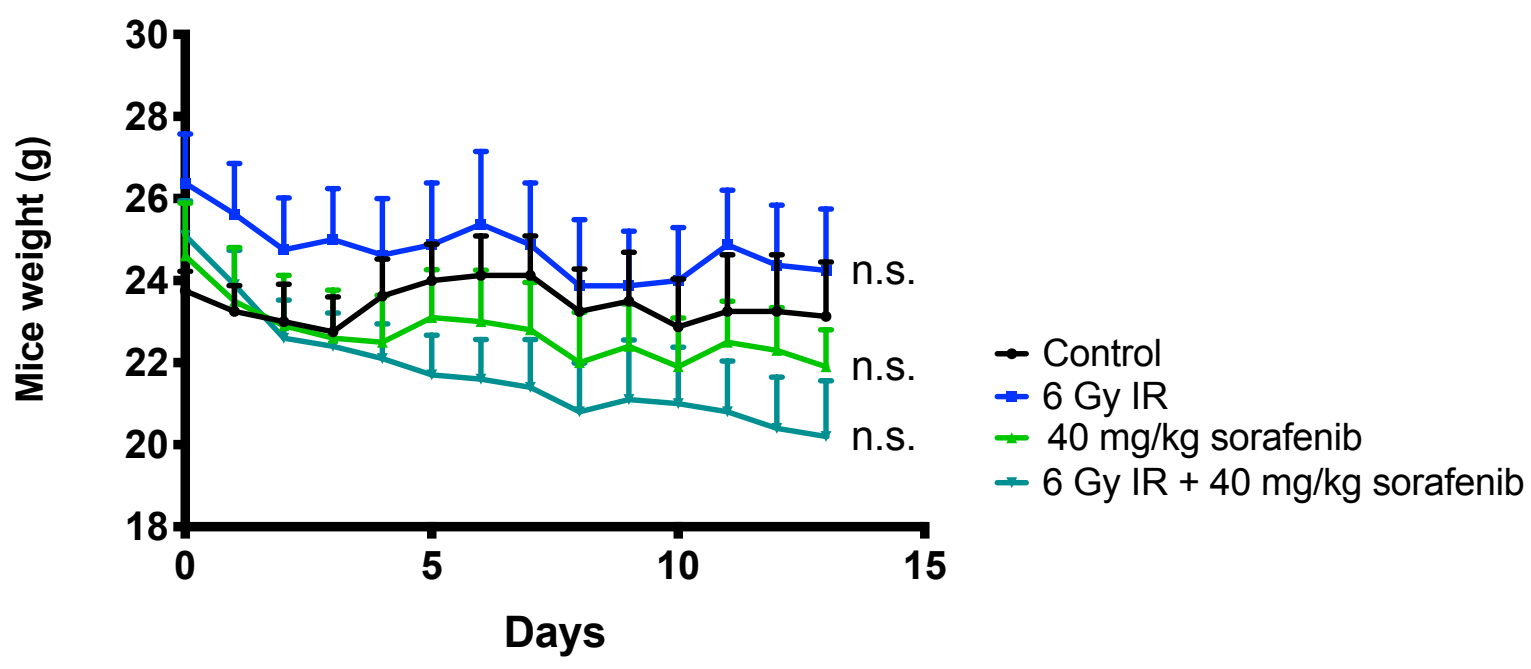

Figure S5. Related to Figure 6 and results section. Mice weight measured by electronic balance over 14 days. Data are plotted as mean \pm SEM; $n=7$ or 8 mice per group for S5A, $n=4$ or 5 mice per group for S5B. 
Figure S6. Related to Figure 6.

A

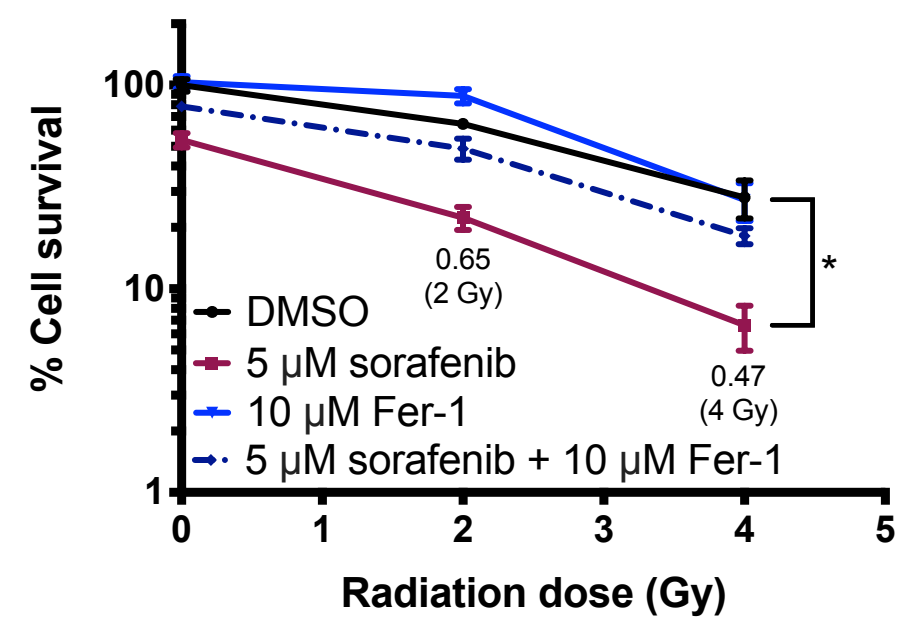

B GSH

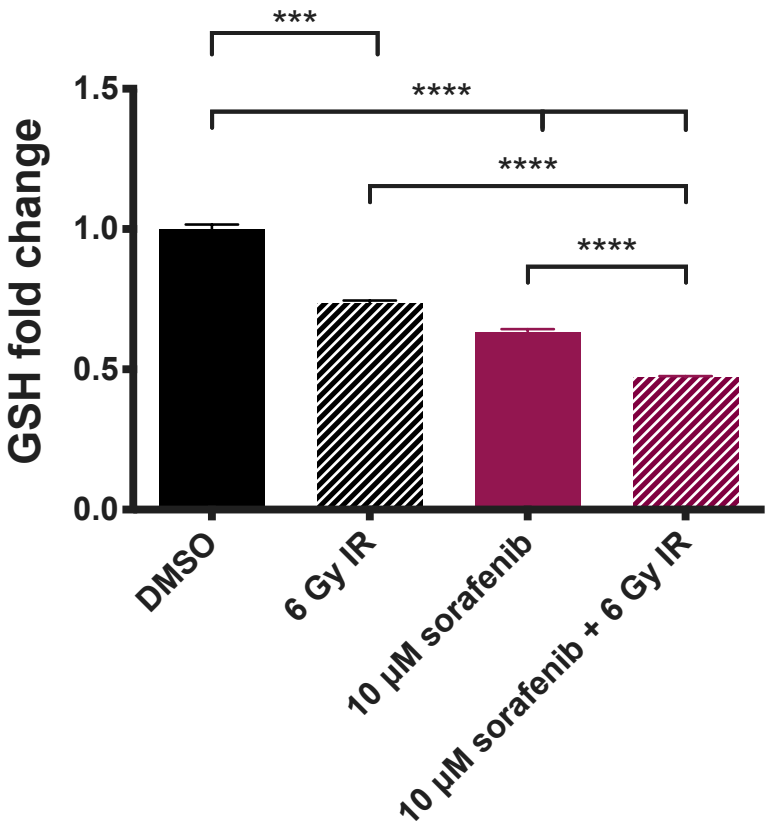

Figure S6. Related to Figure 6 and results section. Effect of sorafenib and radiation on survival and intracellular GSH of HT-1080 cells. A) Dose response of HT-1080 cells treated with DMSO, sorafenib, ferrostatin-1, or sorafenib + ferrostatin-1 to radiation measured by clonogenic assays. $C D I$ values are indicated next to data points according to the formula $C D I=A B /(A \times B)$, where $A B$ is the surviving fraction of the combination treatment, and $A$ and $B$ are the surviving fractions of the individual treatments. B) Reduced glutathione (GSH) level detected in HT-1080 cells treated with DMSO or sorafenib and co-treated with 0 or 6 Gy radiation for 24 hours using a fluorometric assay.

${ }^{* * * *}$ represents $p<0.0001,{ }^{* * *}$ represents $p<0.001,{ }^{*}$ represents $p<0.05$. Data are plotted as mean \pm SEM. $n=3$ side-by-side replicates. 
Figure S7. Related to Figure 7.
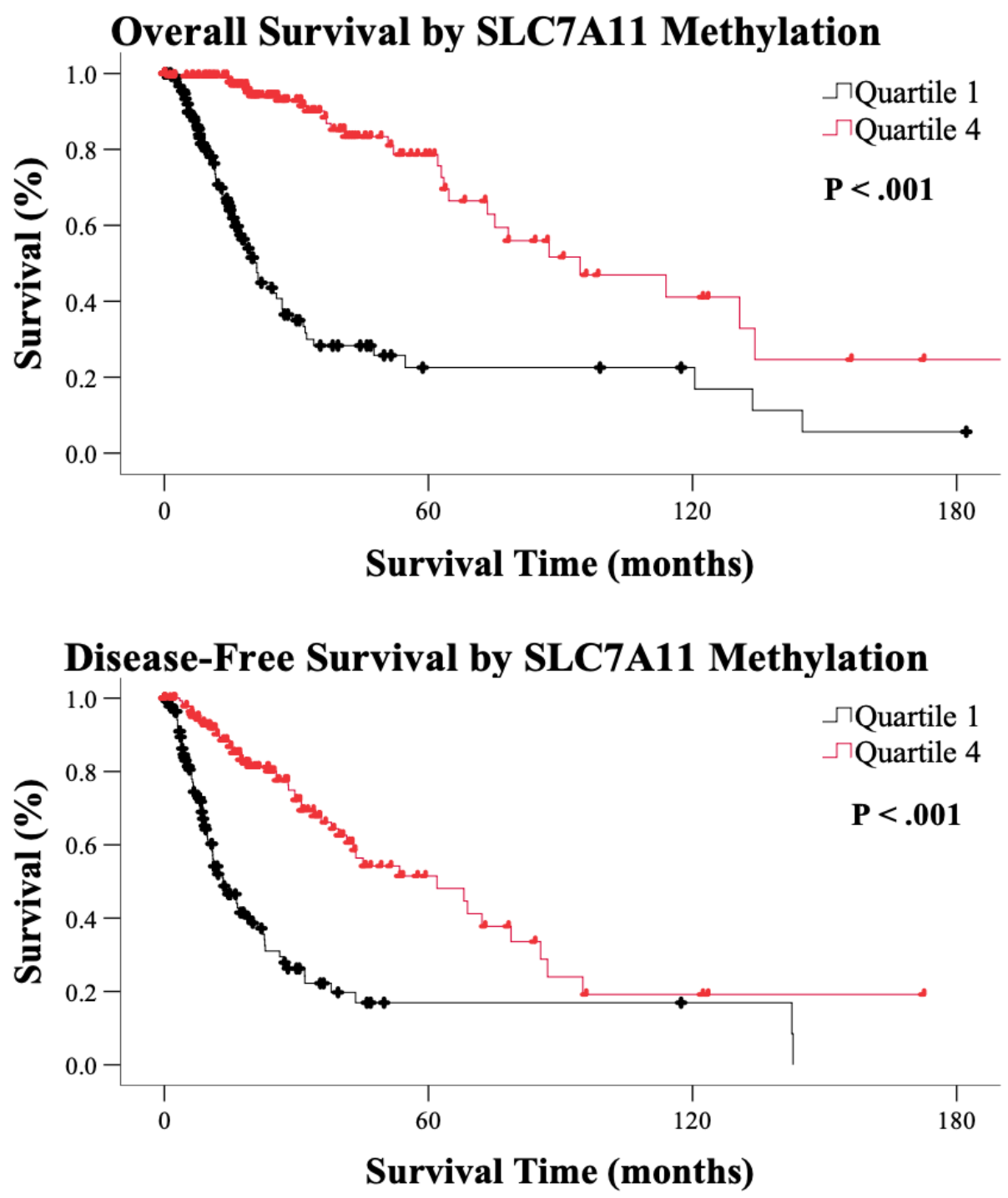

Figure S7. Related to Figure 7 and results section. Kaplan-Meier survival analysis of diseasefree survival of TCGA glioma patients in quartile 1 (low) and quartile 4 (high) of SLC7A11 RNA expression (top) or DNA methylation (bottom). 
Table S1. Related to Figure 1.

Coefficient of Drug Interaction (CDI) values of cell death inducers in combination with IR in HT-1080 cells. Related to Figure 1 and results section.

\begin{tabular}{|c|c|c|}
\hline Inducer & CDI with 2 Gy IR & CDI with 4 Gy IR \\
\hline $300 \mathrm{nM} \mathrm{IKE}$ & 0.35 & 0.17 \\
\hline $20 \mathrm{nM} \mathrm{RSL3}$ & 0.27 & 0.09 \\
\hline $1 \mathrm{nM}$ staurosporine & 1.1 & 0.83 \\
\hline $2 \mathrm{nM}$ doxorubicin & 1.07 & 0.9 \\
\hline $300 \mathrm{nM}$ rapamycin & 0.89 & 0.62 \\
\hline $\begin{array}{c}100 \mathrm{ng} / \mathrm{mL} \text { TNF }+20 \mu \mathrm{M} \\
\text { Z-VAD-FMK }+300 \mathrm{nM} \\
\text { birinapant }\end{array}$ & 0.75 & 0.65 \\
\hline
\end{tabular}

$C D I=A B /(A \times B)$, where $A B$ is the surviving fraction of the combination treatment, and $A$ and $B$ are the surviving fractions of the individual treatments. $C D I<1$ indicates synergy, $\mathrm{CDI}=1$ indicates additivity, and $\mathrm{CDI}>1$ indicates antagonism. 
Table S2. Related to Figure 1.

Highest observed coefficient of Drug Interaction (CDI) values of ferroptosis inducers in combination with IR in HT-1080, SK-LMS-1, U87, A549, and PC9 cells. Related to Figure 1 and results section.

\begin{tabular}{|c|c|c|}
\hline Cell line & IKE + IR & RSL3 + IR \\
\hline HT-1080 & 0.17 & 0.09 \\
\hline SK-LMS-1 & 0.48 & 0.31 \\
\hline U87 & 0.65 & 0.31 \\
\hline A549 & 0.30 & 0.31 \\
\hline PC9 & 0.70 & 0.64 \\
\hline
\end{tabular}

$C D I=A B /(A \times B)$, where $A B$ is the surviving fraction of the combination treatment, and $A$ and $B$ are the surviving fractions of the individual treatments. $C D I<1$ indicates synergy, $\mathrm{CDI}=1$ indicates additivity, and CDI $>1$ indicates antagonism. 
Table S3. Related to Figure 4.

List of the annotated lipids that significantly changed among the groups (Two-way ANOVA; FDR-corrected $p$-value $<0.05)$, including ionization mode as detected adducts (positive/negative), retention time $(R T), \mathrm{m} / \mathrm{z}$ values, mass error $(\Delta \mathrm{ppm})$, molecular formula, and major product ions.

\begin{tabular}{|c|c|c|c|c|c|c|}
\hline Lipids & $\begin{array}{l}\text { Ionization } \\
\text { mode }\end{array}$ & $\begin{array}{l}\text { Retention } \\
\text { time }\end{array}$ & $\begin{array}{c}\mathrm{m} / z \\
\text { observed }\end{array}$ & $\begin{array}{c}\text { Mass } \\
\text { error } \\
(\Delta \mathrm{PPM})\end{array}$ & $\begin{array}{l}\text { Molecular } \\
\text { formula }\end{array}$ & $\begin{array}{l}\text { Major detected } \\
\text { product ions }\end{array}$ \\
\hline FA 16:1 & {$[\mathrm{M}-\mathrm{H}]^{-}$} & 1.99 & 253.2162 & 4 & $\mathrm{C}_{16} \mathrm{H}_{30} \mathrm{O}_{2}$ & 235.2 \\
\hline $\begin{array}{l}\text { LysoPE } \\
16: 0\end{array}$ & {$[\mathrm{M}-\mathrm{H}]^{-}$} & 1.42 & 452.2771 & 2 & $\mathrm{C}_{21} \mathrm{H}_{44} \mathrm{NO}_{7} \mathrm{P}$ & 255.2 \\
\hline $\begin{array}{l}\text { LysoPE } \\
18: 0\end{array}$ & {$[\mathrm{M}-\mathrm{H}]^{-}$} & 2.06 & 480.3084 & 2 & $\mathrm{C}_{23} \mathrm{H}_{48} \mathrm{NO}_{7} \mathrm{P}$ & 283.2 \\
\hline $\begin{array}{l}\text { LysoPE } \\
18: 1\end{array}$ & {$[\mathrm{M}-\mathrm{H}]^{-}$} & 1.49 & 478.2925 & 2 & $\mathrm{C}_{23} \mathrm{H}_{46} \mathrm{NO}_{7} \mathrm{P}$ & 281.2 \\
\hline $\begin{array}{l}\text { LysoPE } \\
\text { P-16:0 }\end{array}$ & {$[\mathrm{M}-\mathrm{H}]^{-}$} & 1.62 & 436.282 & 3 & $\mathrm{C}_{21} \mathrm{H}_{44} \mathrm{NO}_{6} \mathrm{P}$ & 418.2 \\
\hline $\begin{array}{l}\text { LysoPE } \\
\text { P-18:0 }\end{array}$ & {$[\mathrm{M}-\mathrm{H}]^{-}$} & 2.39 & 464.3134 & 2 & $\mathrm{C}_{23} \mathrm{H}_{48} \mathrm{NO}_{6} \mathrm{P}$ & 446.2 \\
\hline $\begin{array}{l}\text { LysoPI } \\
18: 1\end{array}$ & {$[\mathrm{M}-\mathrm{H}]^{-}$} & 1.02 & 597.3045 & 0 & $\mathrm{C}_{27} \mathrm{H}_{51} \mathrm{O} 12 \mathrm{P}$ & $281.2 / 241.2$ \\
\hline $\begin{array}{l}\text { LysoPC } \\
16: 0\end{array}$ & $\begin{array}{l}{\left[\mathrm{M}+\mathrm{CH}_{3} \mathrm{C}\right.} \\
\mathrm{OO}]\end{array}$ & 1.34 & 554.3452 & 2 & $\mathrm{C}_{24} \mathrm{H}_{50} \mathrm{NO}_{7} \mathrm{P}$ & $480.3 / 255.2$ \\
\hline $\begin{array}{l}\text { LysoPC } \\
18: 0\end{array}$ & $\begin{array}{l}{\left[\mathrm{M}+\mathrm{CH}_{3} \mathrm{C}\right.} \\
\mathrm{OO}]\end{array}$ & 1.93 & 582.3767 & 1 & $\mathrm{C}_{26} \mathrm{H}_{54} \mathrm{NO}_{7} \mathrm{P}$ & $508.3 / 283.2$ \\
\hline $\begin{array}{l}\text { LysoPC } \\
18: 1\end{array}$ & $\begin{array}{l}{\left[\mathrm{M}+\mathrm{CH}_{3} \mathrm{C}\right.} \\
\mathrm{OO}]^{-}\end{array}$ & 1.42 & 580.3615 & 0 & $\mathrm{C}_{26} \mathrm{H}_{52} \mathrm{NO}_{7} \mathrm{P}$ & $506.3 / 281.2$ \\
\hline $\begin{array}{l}\text { DAG } \\
16: 0 \quad 16: 0\end{array}$ & $\begin{array}{l}{[\mathrm{M}+\mathrm{H}-} \\
\left.\mathrm{H}_{2} \mathrm{O}\right]^{+}\end{array}$ & 13.69 & 551.504 & 0 & $\mathrm{C}_{35} \mathrm{H}_{68} \mathrm{O}_{5}$ & 313.3 \\
\hline $\begin{array}{l}\text { DAG } \\
16: 0 \quad 16: 1\end{array}$ & $\begin{array}{l}{[\mathrm{M}+\mathrm{H}-} \\
\left.\mathrm{H}_{2} \mathrm{O}\right]^{+}\end{array}$ & 12.95 & 549.4883 & 0 & $\mathrm{C}_{35} \mathrm{H}_{66} \mathrm{O}_{5}$ & $313.3 / 311.3$ \\
\hline $\begin{array}{l}\text { DAG } \\
\text { 16:0_18:1 }\end{array}$ & $\begin{array}{l}{[\mathrm{M}+\mathrm{H}-} \\
\left.\mathrm{H}_{2} \mathrm{O}\right]^{+}\end{array}$ & 13.74 & 577.5191 & 0 & $\mathrm{C}_{37} \mathrm{H}_{70} \mathrm{O}_{5}$ & $313.3 / 339.3$ \\
\hline $\begin{array}{l}\text { DAG } \\
16: 1 \quad 18: 0\end{array}$ & $\begin{array}{l}{[\mathrm{M}+\mathrm{H}-} \\
\left.\mathrm{H}_{2} \mathrm{O}\right]^{+}\end{array}$ & 14.30 & 577.5167 & 4 & $\mathrm{C}_{37} \mathrm{H}_{70} \mathrm{O}_{5}$ & 341.3 \\
\hline $\begin{array}{l}\text { LysoPC } \\
16: 0\end{array}$ & {$[\mathrm{M}+\mathrm{H}]^{+}$} & 1.36 & 496.3407 & 1 & $\mathrm{C}_{24} \mathrm{H}_{50} \mathrm{NO}_{7} \mathrm{P}$ & $\begin{array}{l}\text { 184.07/(Acyl chain } \\
\text { was confirmed in } \\
\text { negative mode; } \\
255.2 \text { ) }\end{array}$ \\
\hline $\begin{array}{l}\text { LysoPC } \\
18: 0\end{array}$ & {$[\mathrm{M}+\mathrm{H}]^{+}$} & 1.93 & 524.3717 & 1 & $\mathrm{C}_{26} \mathrm{H}_{54} \mathrm{NO}_{7} \mathrm{P}$ & $\begin{array}{l}184.07 /(\text { Acyl chain } \\
\text { was confirmed in } \\
\text { negative mode; } \\
283.2 \text { ) }\end{array}$ \\
\hline $\begin{array}{l}\text { LysoPC } \\
18: 1\end{array}$ & {$[\mathrm{M}+\mathrm{H}]^{+}$} & 1.42 & 522.3566 & 2 & $\mathrm{C}_{26} \mathrm{H}_{52} \mathrm{NO}_{7} \mathrm{P}$ & $\begin{array}{l}184.07 / \text { Acyl chain } \\
\text { was confirmed in }\end{array}$ \\
\hline
\end{tabular}




\begin{tabular}{|c|c|c|c|c|c|c|}
\hline & & & & & & $\begin{array}{l}\text { negative mode; } \\
253.2 \text { ) }\end{array}$ \\
\hline $\begin{array}{l}\text { LysoPC } \\
\text { O-16:0 }\end{array}$ & {$[\mathrm{M}+\mathrm{H}]^{+}$} & 1.59 & 482.3611 & 1 & $\begin{array}{l}\mathrm{C}_{24} \mathrm{H}_{52} \mathrm{NO6} \\
\mathrm{P}\end{array}$ & $184.07 / 104.1$ \\
\hline $\begin{array}{l}\text { LysoPE } \\
18: 0\end{array}$ & {$[\mathrm{M}+\mathrm{H}]^{+}$} & 2.05 & 482.3247 & 1 & $\mathrm{C}_{23} \mathrm{H}_{48} \mathrm{NO}_{7} \mathrm{P}$ & $\begin{array}{l}\text { Neutral loss of } \\
141.2 / \text { Acyl chain } \\
\text { was confirmed in } \\
\text { negative mode; } \\
283.2 \text { ) }\end{array}$ \\
\hline $\begin{array}{l}\text { LysoPE } \\
18: 1\end{array}$ & {$[\mathrm{M}+\mathrm{H}]^{+}$} & 1.49 & 480.3104 & 4 & $\mathrm{C}_{23} \mathrm{H}_{46} \mathrm{NO}_{7} \mathrm{P}$ & $\begin{array}{l}\text { Neutral loss of } \\
141.2 / \text { Acyl chain } \\
\text { was confirmed in } \\
\text { negative mode; } \\
281.2 \text { ) }\end{array}$ \\
\hline $\begin{array}{l}\text { LysoPE } \\
\text { P-16:0 }\end{array}$ & {$[\mathrm{M}+\mathrm{H}]^{+}$} & 1.62 & 438.2983 & 0 & $\mathrm{C}_{21} \mathrm{H}_{44} \mathrm{NO}_{6} \mathrm{P}$ & 242.2 \\
\hline $\begin{array}{l}\text { LysoPE } \\
\text { P-18:0 }\end{array}$ & {$[\mathrm{M}+\mathrm{H}]^{+}$} & 2.40 & 466.3296 & 0 & $\mathrm{C}_{23} \mathrm{H}_{48} \mathrm{NO}_{6} \mathrm{P}$ & 325.2 \\
\hline $\begin{array}{l}\text { DAG } \\
16: 0 \_16: 0\end{array}$ & {$[\mathrm{M}+\mathrm{Na}]^{+}$} & 13.69 & 591.496 & 0 & $\mathrm{C}_{35} \mathrm{H}_{68} \mathrm{O}_{5}$ & 313.3 \\
\hline $\begin{array}{l}\text { DAG } \\
\text { 16:0 16:0 }\end{array}$ & {$\left[\mathrm{M}+\mathrm{NH}_{4}\right]^{+}$} & 13.69 & 586.5407 & 0 & $\mathrm{C}_{35} \mathrm{H}_{68} \mathrm{O}_{5}$ & 313.3 \\
\hline $\begin{array}{l}\text { DAG } \\
16: 0 \quad 16: 1\end{array}$ & {$\left[\mathrm{M}+\mathrm{NH}_{4}\right]^{+}$} & 12.95 & 584.5253 & 0 & $\mathrm{C}_{35} \mathrm{H}_{66} \mathrm{O}_{5}$ & $313.3 / 311.3$ \\
\hline $\begin{array}{l}\text { DAG } \\
16: 0 \quad 18: 1\end{array}$ & {$\left[\mathrm{M}+\mathrm{NH}_{4}\right]^{+}$} & 13.73 & 612.5563 & 0 & $\mathrm{C}_{37} \mathrm{H}_{70} \mathrm{O}_{5}$ & 313.3/339.3 \\
\hline $\begin{array}{l}\text { DAG } \\
16: 1 / 18: 1\end{array}$ & {$\left[\mathrm{M}+\mathrm{NH}_{4}\right]^{+}$} & 13.34 & 610.5395 & 1 & $\mathrm{C}_{37} \mathrm{H}_{68} \mathrm{O}_{5}$ & $311.3 / 339.3$ \\
\hline $\begin{array}{l}\text { DAG } \\
24: 0 \_24: 1\end{array}$ & {$\left[\mathrm{M}+\mathrm{NH}_{4}\right]^{+}$} & 17.40 & 808.7745 & 0 & $\mathrm{C}_{51} \mathrm{H}_{98} \mathrm{O}_{5}$ & 425.4 \\
\hline
\end{tabular}


Table S4. Related to Figure 7.

Characteristics of human gliomas from which organotypic brain slice cultures were derived. Related to Figure 7 and results section.

\begin{tabular}{|c|c|c|c|}
\hline Tumor bank ID & Age & Sex & Diagnosis \\
\hline \multicolumn{4}{|c|}{ Positive response to radiation } \\
\hline 6163 & 23 & M & Diffuse Astrocytoma, grade II \\
\hline 6177 & 52 & M & Anaplastic Astrocytoma, grade III \\
\hline 6181 & 32 & F & Anaplastic Oligodendroglioma, grade III \\
\hline \multicolumn{2}{|c|}{ Negative response to radiation } & \\
\hline 6186 & 66 & M & Glioblastoma, grade IV \\
\hline 6193 & 67 & M & Glioblastoma, grade IV \\
\hline
\end{tabular}

